\title{
Strategic Agricultural Commodity Value Chains in Africa for Increased Food: The Regional Approach for Food Security
}

\section{Mahamadou Nassirou Ba}

Food Security, Agriculture and Land Section in the Regional Integration and Trade Division, United Nations Economic Commission for Africa, Addis Ababa, Ethiopia

Email: nassiroub@gmail.com

How to cite this paper: Ba, M.N. (2016) Strategic Agricultural Commodity Value Chains in Africa for Increased Food: The Regional Approach for Food Security. Agricultural Sciences, 7, 549-585. http://dx.doi.org/10.4236/as.2016.79055

Received: May 26, 2016

Accepted: September 10, 2016

Published: September 14, 2016

Copyright $\odot 2016$ by author and Scientific Research Publishing Inc. This work is licensed under the Creative Commons Attribution International License (CC BY 4.0).

http://creativecommons.org/licenses/by/4.0/ (c) (i) Open Access

\section{Abstract}

The challenge Africa faces the most is how to feed the 2.4 billion people in 2050 . This will require a transformational agriculture. Africa doesn't need subsistence agriculture, but rather agriculture linked to the market where market demand and the consuming habits are taken in consideration. Agriculture evolves in an environment where small holders are linked to markets (national and regional), where economies of complementarity and economies of scale are taken advantage of by producers and private sector. In short, Africa will need a paradigm shift to industrialise and commercialise its agriculture sector in order to increase food production, and income and to create jobs in and outside the sector. Africa needs agribusiness and agro-industries to domesticate the benefits of the sector, to create wealth in the sector and retain that wealth in the continent. Agricultural commodities regional value chains for increased food should be the target for Africa. The continent remains the region with the highest prevalence of under-nourishment. Since agriculture remains the mainstay of most African economies except the mineral producers, the sector deserves a close attention from leaders. It accounts for $65 \%$ of employment and $40 \%$ of Africa's export earnings and accounts for $17 \%$ of the GDP. This shows how important the sector is. Agriculture needs to be seen as a conduit for farmers to get connected to markets, a conduit for revenue, for jobs and for transformation. Africa needs to come back on the international scene as food sufficient continent and even food exporter. This can be achieved only with a stable, productive agricultural resource base. Thus, achieving and sustaining food security and economic prosperity in Africa will require significant efforts to modernize the continent's agriculture sector through injection of agribusiness and agro-industries and through the application of science and technology in agriculture. In essence, agriculture needs to be viewed as knowledge based entrepreneurial activity. Smart investments in agriculture will have 
multiplier effects for the whole economy and hence induce prosperity to other sectors. In recent years, a renewed focus on agriculture has been evident in policy and development agendas across the African continent. This paper outlines the status of agriculture, agribusiness and agro-industries in Africa, their role in the agenda of agricultural transformation and economic transformation and the focus on regional value chain to increase food production, transformation and trade. The paper adopts a new thinking in agriculture, which reflects a regional value chain approach. The author covers such issues as: need for agricultural transformation, the role of value chain in agricultural sector, the need for regional value chain for increased income and increased food, the role of markets and the common denominator of all, the regional integration to push forward the African agriculture agenda. Evidence shows that it is agricultural growth, through its leverage effects on the rest of the economy that typically enables poor countries, poor regions and ultimately poor households to take the first steps toward economic transformation. Therefore agricultural productivity, at the small holder's level, has the potential to lift millions of Africa's vulnerable out of poverty and provide sustainable jobs. Other factors, namely "the rapid urbanization" and "increased population growth", are quoted to be of critical importance. Africa population is projected to double, attaining the 2.3 billion people mark over the next 40 years representing half of the globe's total population. This could trigger competition for resources and can have devastating effects on natural resources if not rightly channelled.

\section{Keywords}

Food Security, Agricultural Commodities Value Chain, Regional Value Chains, Agricultural Transformation, Agribusiness, Agro-Industries

\section{Introduction}

Increased food production, availability, access and utilisation, are the ultimate goals for most African nations. Food security exists "when all people, at all times, have physical and economic access to sufficient, safe, nutritious food to meet their dietary needs and food preferences for an active life" [1]. While on the other hand, the concept of food insecurity is closely linked with the poverty in country. According to the United Nation Development Programme Human Development report [2] on food insecurity, the phenomenon is closely linked to poverty, income and unemployment. Therefore Africa has been striving to achieve the food security goals for decades. Achieving them is critical as Africa population is on the rise and disproportion between supply and demand of food is also widening. In October 2011, the world population passed the 7 billion mark. Furthermore, the world population is projected to exceed 10 billion at the end of the century. Africa, by far the world's poorest region, will record the largest amount of population growth of any world region between now and 2050. Africa's population is expected to more than double, rising from 1.1 billion today to at least 2.4 billion by 2050. "Nearly all of that growth will be in the 51 countries of sub-Saharan Af- 
rica, the region's poorest", from report of Population Reference Bureau (PRB) [3]. "Rapid population growth makes it difficult for economies to produce enough food, create enough jobs to lift large numbers of people out of poverty". Such growth will put a massive strain on the global food supply. In addition, Africa will have an unprecedented urban population composed by a large part by its middle class population and youth. That emerging middle class is now used to new dietary habits, such as readymade and package food (cereals, meats and dairy products). For all the above reasons, Africa needs to transform its agriculture, bring about agribusiness and agro-industries to link farms to markets, create jobs, and create revenues, and link up other sectors to agriculture.

The African Union (AU), through its New Partnership for Africa's Development (NEPAD), is providing leadership and support via NEPAD's Comprehensive Africa Agriculture Development Programme (CAADP). Through this program AU is encouraging countries to develop investment plans and to allocate at least $10 \%$ of their annual national budgets to agriculture. Clearly, recent sharp increases in international food prices are contributing to increased food import bills in the short run. However, improved performance in Africa's agriculture sector through increased public and private investment and targeted interventions can help offset those short-term effects and over the longer term. Achieving the African Agenda of attaining an average of 6\% growth rate in agriculture will not only support sustained overall economic growth, but will also open up major opportunities for African farmers in domestic, regional and international markets. We need to enhance our collective efforts to achieve both food and nutritional security in Africa and we urge all the stakeholders in agriculture to sustain the momentum through collaboration.

Solution for this new equation has to necessarily pass through the agricultural food systems and value chains development, namely agribusiness and agro-industries development. This alone makes the production and distribution of food a critical issue for Africa. This is a problem and Africa needs to solve it. For instance, the population of Niger, the country with the highest total fertility rate in the world, is projected to grow from 14 million (2006 base data) to 58 million in 2050, a 4.3 -fold increase, while in Uganda for the same period it will be from 30 to 91 million, and so on for a number of other countries in Africa [4]. It is worth noting that the 2008 phenomena of food price increase and volatility and food scarcity have triggered changes in the food and agriculture sector as well. Efforts are being made to reduce levels of food insecurity both at regional, national and household levels.

At AU level, the food security issue is being tackled through the NEPAD/CAADP framework as mentioned above. Significant political attention has been given to the promotion of improvements in food staples productivity in African countries, both to offset the rapidly increasing costs of food imports, and to stimulate increased incomes and hence food security status at the household level. This attention has been manifested at national level, with many countries placing food staples and agricultural value chains at the centre of their National Agriculture and Investment development Pro- 
grammes (NAIP) with the implementation of the CAADP compact, as well as regional level within RECS agricultural strategies. A central focus of these initiatives has been to develop and advocate for mechanisms that will result in increased production by smallholders through the adoption of productivity enhancing technologies and to facilitate access to critical inputs as well as link smallholders to the markets.

As far as small holders are concerned, reducing their risks is a big deal for them. They don't want to get involved in anything if they don't see their benefits. As such, there must be parallel focus on market access so that farmers can benefit from the potential production increase in terms of increased network and increased income. If the small farmer doesn't see that increase productivity will translate in increase income, there will not be any motivation. CAADP Pillar $2^{1}$ which aims to increase market access through improved rural infrastructure and other trade-related interventions sets specific objectives to include small holders' wealth and well-being. As such its objectives are: (i) to accelerate growth in the agricultural sector by raising the capacities of private entrepreneurs (including commercial and small-holder farmers) to meet the increasingly complex quality and logistic requirements of markets, focusing on selected agricultural commodities that offer the potential to raise rural (on- and off-farm) incomes, and (ii) to create the required regulatory and policy framework that would facilitate the emergence of regional economic spaces that would spur the expansion of regional trade and cross-country investments. Abiding to the framework of the CADDP, member states should all support the promotion of agricultural commodities value chains as a mean to increase food production, which is the theme of this report. It is worth recalling that studies have proven that only $1 \%$ increase in per capita GDP in agriculture reduces the depth of poverty by at least 5 times more than a similar increase outside the agricultural sector [5]. Also 1 percent increase in agricultural GDP growth is translated to $4 \%$ in economic growth [6] Africa green revolution should start by its agricultural transformation as shown in Gallup et al. (1997) [7], "that every 1\% growth in per capita agricultural GDP led to $1.61 \%$ growth in the incomes of the poorest $20 \%$ of the population-much greater than the impact of similar increases in the manufacturing or service sectors".

In terms of the role of agricultural productivity in reducing poverty, Thirtle et al. (2001) [8] concluded from cross-country regression analysis that, on average, every $1 \%$ increase in labour productivity in agriculture reduced the number of people living on less than a dollar a day by between $0.6 \%$ and $1.2 \%$. No other sector of the economy shows such a strong correlation between productivity gains and poverty reduction. The routes through which growth in agriculture achieve such a potent impact on poverty are among other things through the development of agribusiness and agro-industries with the view of regional value chain approach detailed below in this report. Africa should capitalise in this in its era pf transformation.

Today one of the core development strategies recommended by reputable institutions such as United Nations Economic Commission for Africa (UNECA) is the pro${ }^{1}$ CAADP: Comprehensive Africa Agriculture Development programme: http://www.nepad-caadp.net/download/file/fid/210 
motion of "commodity based industrialization" anchored in the development of strategic agricultural commodity value chains from the small holder's level at the farm gate, to the consumer table, supported by the development of infrastructure including Small Medium Enterprises (SME) and Small Medium Industries (SMI).

To achieve this Africa needs to:

1) develop and implement policies and programs to accelerate industrialization with a focus on regional infrastructure, regional value chains, food security and agricultural transformation, and

2) develop and implement policies and programs in the areas of intra-African and international trade and investments, as well as

3) design and implement land policies and programs that ensure and secure gender equitable land rights, effective and efficient use and management of land for sustainable development.

\section{Key Messages}

- Agribusiness and Agro-industries through agricultural commodities value chains should be used as a conduit to help Africa to increase production and productivity of the agricultural sector. There is a crucial need as Africa population is rising, creating a discrepancy between supply and demand of food. At the same time the type of food demanded, especially in urban areas is also changing.

- Small holder farmers (mostly women) represent $80 \%$ of all farms in sub-Saharan Africa and contribute up to $90 \%$ of food production in some countries. In an unstructured and non-formalised value chains environment, the risks and unit costs are often too high for smallholders to viably access markets, inputs and services. This in turn impacts the efficiency at the farm level, impacting of the production and productivity.

- It also impacts on the viability of small agribusiness and agro-industries units undertaking value-adding activities such as processing. Investment and growth will only happen inclusively, if smallholders' production can be commercialised and agricultural SMEs/SMIs made more resilient.

- To benefit from economies of complementarity and economies of scale, it is encouraged to open up borders and frontiers and take advantage of comparative and competitive advantages, firm up the free trade areas at RECs level and build the continental free trade are (CFTA) which is the ultimate goal of AU today.

- For the sake of "increased Food Production", smallholder farmers' participation in markets is crucially important for improved food security and poverty reduction. They must be connected to the input-market as well as the output market. First at the household level and then extended to national, regional and continental level. The small holders need to be part of the value chain and not only to be and remain the stepping stone of it. Attempts to improve small holders' productivity will have limited success if the linkages to markets are not strengthened simultaneously.

- There is a need for a paradigm shift in political decision to revitalise the role of 
small holders in agricultural growth so that the growth is inclusive from the farm level upwards. Limited smallholders' participation in markets is not necessarily a result of a lack of commercial orientation per se, but the result of constrained choice in a risky environment. This needs to change.

- The development of agribusiness and agro-industries through commodities value chains should be supported market driven production. This should take in account that smallholders are very heterogeneous, facing different types of constraints according to the commodities, and will react differently to new market opportunities.

- Regional Value Chain, in the context of a strong regional integration, supported by CFTA could trigger increased productivity in the food sector and serve as a conduit to reduce food insecurity by increased employment opportunities and increased income levels.

- Policy interventions need to be prioritized and sequenced according to evidencebased diagnosis of the constraints faced by different categories of small holders as evidence-based policy-making minimizes the risks of policy failure.

- Public policy interventions are generally needed to foster smallholder market integration. Public Private Partnership needs to be encouraged to support value chains actions.

\section{Background}

\section{State of African Agriculture}

African agriculture has been for past decades the backbone of its economic development. During the past thirty years the competitiveness of many African export crops has declined, and Africa's dependence on imported food crops has increased. While the poor performance of African agriculture can be attributed partly to adverse agro-ecological conditions, experience from elsewhere in the developing world suggests that significant progress is possible. Nonetheless, on a positive note, recent years have seen the mineral and other natural resources sector emerging to support several countries' economic development. Regardless of the status of other emerging sectors, agriculture sector has remained the main activity of at least 75 percent of the population. Unfortunately the vast population of the continent, engaged in agriculture, as wage earners or self employed remains the poorest in the continent or even in the world, due mainly to the continued low performance of the sector.

African agriculture has remained traditional for the most part with a little modernization. Many studies and reviews revealed that Africa missed the "green revolution" of the 1960's which propelled most Asian countries to agricultural and rural transformation and subsequent food sufficiency and inter linkages among economic sectors. But the question remains to ask, if that was a good or a bad thing? There are many debates going on the subject, some scientists think that Africa might not have been ready for that green revolution due to the fact that it was based on high fertilizer use and intensive irrigation coupled with high pesticide use At that period, accessibility to these three catalysts could have been a problem for the majority of Africa farmers. In any case the 
green revolution was not without high costs. Indeed the consequence of the green revolution has been an increase in yields for specific crops in specific countries, but beyond the yield gain, there were many other costs, such as economic, agricultural and social. The programme used large amount of water, fertilizers and chemicals pesticides, which in the end, impoverished soils, leaving them less fertile and in some cases highly polluted. As a result, local biodiversity was drastically reduced, creating dependence on pesticides (GRAIN, 2007) [9]. Some other scientists think that probably Africa needs its own green revolution, carved to take in account specificities of African agriculture.

The fact remains that Africa has been unable to secure food for all its population and to design any sustainable pathway for its own food security: ${ }^{2}$ It is certain that Africa food security has been affected by a complexity of factors; nonetheless, a structural transformation in agriculture could take it to a new dimension and unfold some viable solutions. Agriculture being the largest employer of labor in Africa, and having an enormous role to play in the development of the continent, efforts should be put to the rethinking of agricultural and rural transformation to help Africa agriculture moved to the next stage. Currently the productivity in the sector is either stagnating or subject to very slow increase, for several countries across the whole sub-region and that despite all the different programmes tried so far from the 1960s to now (FAO, 2009). Numerous reasons have been advanced for this stagnation, including secular inefficient traditional way of exploiting land, inadequate returns from investments in agricultural research, low inputs, lack of efficient technology, high exposure to risks, limited risk management capacity, lack of training, inappropriate government policies and development efforts, etc. There are few exceptions to be noted. In some African countries, agricultural research has generated several kinds of technology with high potential, but even then, the impact of the technology on farmers' productivity, livelihood and quality of life have not matched to the level of that potential, due to inappropriate extension techniques, and sometimes, lack of funds to support good initiatives. But some elite farmers did benefits from those initiatives.

African agriculture still lags behind and has not been able to be the propeller of other sectors of the economies as was seen in most Asian and Western countries during their green revolutions.

Africa now found itself in a cross road where its food security and poverty issues, are getting even more complicated to solve with a increasing population growth rate, increasing global warming impact on productivity and soil aridity and other related environmental issues, decreasing water and land availability, increasing food and energy prices, consequences of World financial and economic crises, etc. It is now adamant that agricultural and rural transformation be taken seriously as a pathway to get Africa out of poverty and food insecurity as stated by NEPAD's Rural Futures.

This NEPAD programme is a result of a joint effort (NEPAD, ECA, WWF and regional partners) to respond to the challenge and opportunities of rural Africa. Its main

${ }^{2}$ Food Security is defined here as "a situation in which all people, at all times, have physical, social and economic access to sufficient, safe and nutritious food to meet their dietary needs and food preferences for an active healthy life." (FAO, 1998). 
objective is to carve actions resulting from in depth analysis and prospects for the rural sector in the context of the global market economy. It builds on the ongoing work and experience of member states, regional bodies, civil society, the private sector and international partners.

There are good reasons to be optimistic about the future of rural economy in Africa. Following a long period of neglect, it is now clear that Africa cannot escape to go through agricultural transformation and rural transformation in order to get to the next level. The NEPAD/CAAD and the declaration of Maputo should serve as base to boost the rethinking of Africa agricultural and rural transformation. In several countries, taxation of the sector has been reduced, and public investment in agriculture has picked up. With continued political commitment backed by tangible actions, prospects are bright that the vast potential of African agriculture may soon be unleashed.

\section{Objectives of the Study Methodology and Structures}

\subsection{Objective of the Study}

- The main objective of this study is to explore and propose concrete recommendations on relevant policies and programs/ projects, necessary for effective development of value chains, based on a deeper analysis of value chains of agricultural commodities as a mean for increased food production, and development of agribusiness and agro-industries in Africa through processing and transformation.

- The specific objectives are

1) to push the agenda of the development and promotion of agricultural commodities value chain to be a mean to achieve food security and the strategy of accelerated growth in Africa.

2) to demonstrate and inform stakeholders and policy makers of the transformational benefits of the use of agricultural value chains in promoting Africa's agriculture and to seek broad support for adoption of the value chain approach in the national and regional development frameworks.

3) to encourage the African states to embrace the agricultural value chain approach, and the private sector to engage with the public sector in promoting greater investments in the sector, with the ultimate aim of enhancing food security and increasing farmers' incomes, in line with long-term development strategies.

4) To bring focus on maximizing value addition to primary production by diversifying away from sustenance and subsistence based farming approaches.

\subsection{Methodology of the Analysis}

The present paper was prepared and intended to be a contribution to the African Development Bank (AfDB) Annual Meeting held in Kigali in 2014 on the theme: Promoting Agricultural Value Chains in Africa. It was a" desk research study". The content relied on documents and researches on existing work and analyses by specialists, sponsors, researchers and international organisations active in agriculture. This was mixed with the core approach taken by the author regarding agricultural transformation and 
agricultural commodities value chain. Internet was used (websites referenced) so are magazines and publications on the subject. It referred also to several value chains studies done by United Nations Economic Commission for Africa (UNECA) in the past.

\subsection{Structure of the Analysis}

The paper is made up of seven chapters: The introductory chapter 1 consists of the justification, background and context, the objective of the study, the methodology applied and the structure of the analysis. The second chapter describes the objectives, methodology and structure of the study, while chapter 3 highlights the characteristics of the African agriculture and reiterates the need for an agricultural transformation with emphasis on production, productivity and the issue of smallholders' double disconnection. Chapter 4 details the role of value chains in agriculture in Africa. The need for a regional value chains in the agricultural sector for increased income and increased food production is described in chapter 5 with emphasis on the role of the small holder farmers and the access to technology infrastructure and sector linkages. The ultimate role of agribusiness and agro-industries is addressed in chapter 6, starting with the state of Africa agribusiness landscape, the impact of the Agribusiness, Agro-Industries in Africa Initiative (3ADI) and the need for a commodity based industrialisation. In chapter 7, enhancing regional markets and trade is addressed with emphasis on the role of trade, regional markets and regional integration is emphasised as a sure pathway for a sustained agricultural and economic growth. Thus the chapter highlights the need for an accelerated Continental Free Trade Area (CFTA) and Boosting Intra Africa Trade (BIAT). The last chapter of the study focuses on value chain financing as a sine qua non condition for the agricultural transformation and the achievement of the expected accomplishment listed in the study. The study is concluded by highlighting relevant and actionable recommendations on the value chain as a mean of increased production, increased income and subsequently increased economic growth and prosperity.

\section{Characteristics of African Agriculture}

Africa's agriculture remains under-developed and characterized by the predominance of primary agriculture products. It is mostly subsistence farming with low fertility soils, minimal use of external farm inputs, low productivity, minimal diversification, environmental degradation, therefore low inputs and low output. This is coupled with significant food crop loss both pre- and post-harvest, minimal value addition and product differentiation. Ninety five percent of the food in Sub-Saharan Africa is grown under rain fed agriculture (UNECA, 2009) [10]. Hence food production is vulnerable to adverse weather conditions. These days' climate change effects are visible and droughts are becoming more severe and famines deadly. There is an overall decline in farm input investment including fertilizers, seeds, and technology adoption. Accessibility to fertilizer is not obvious as it is not only costly sometimes but also not available widely although many governments adopted market liberalization to facilitate fertilizers imports

or even subsidized their use. But still efforts are insufficient to bring about wanted 
changes. The limited access to credits markets and infrastructure limit development of output, and also limit farmer's ability to purchase fertilizer and other inputs, consequently the inter-linkage among sectors is hampered.

On the other hand, there is a positive note. The wealth of Africa is undeniable when it comes to natural resources. Africa remains the most endowed continent. Its abundant arable land, water resources and available cheap labor could easily be translated to increase production, incomes and food security, if they are supported by sound conducive policies. It is well known that agriculture is the sector with high multiplier effect translating to income generation, social and economic returns and welfare, leading to economic diversification. Nonetheless, it continues to be low priority and/or not getting enough attention and resources. Small scale farming remains the main implementation method and it is mostly rain fed which is characterized by low yields. African farmers have found themselves trapped in a vicious circle of poverty and food insecurity, not being able to suffice to their own basic needs. As long as the share of Africa agriculture in its GDP will remains high, it means "structural transformation" has still not taken place, because in the process other sectors are supposed to take over the main share of the GDP while agriculture still goes strong in real terms (John Staatz, 2007). African agriculture contributes 29.2 percent of GDP in 1979-81 and 24.6 percent in 2002-2004 and 16.4 percent in 2005 compared with the world average of 7percent in 1981 and 3 percent in 2004. The performance of African agriculture has been somewhat disappointing over many decades. As such Africa is the only region of the world where per capita food production has been declining over the past three decades. As a result, there is increasing rural poverty, rising food prices, widespread famines and increasing food imports.

\subsection{Need for Agricultural Transformation in Africa}

\subsubsection{Agricultural Transformation}

African agriculture can and need to be transformed, in order to make a greater contribution to its food security and the continent's economic prospects.

Agricultural transformation is the process by which individual farms shift from highly diversified, subsistence-oriented production towards more specialized production oriented towards markets or other systems of exchange (e.g. long contracts). The process involves a greater reliance on input and output delivery systems and increased integration of agriculture with other sectors of domestic and international economies (Staatz, 1998) [11]. Agricultural transformation is part of a greater structural transformation, a process by which the relative contribution of non-agricultural sectors to the overall economy rises as agriculture's share declines in relative terms" (UNECA-ERA, 2005) [12] But during structural transformation, agriculture will continue to grow and contribute to overall economic growth, in absolute terms. It usually translates by increasing proportion of economic output and employment by sectors others than agriculture. Agriculture transformation is therefore part of the rural transformation which impacts other economic and social factors in the rural economy. 
Investing in agriculture is one of the most effective ways to achieve food security and drive inclusive growth. The agriculture sector employs $65 \%-70 \%$ of the African workforce. It accounts for about a third of the continent's GDP. There is a fast-growing regional food market which is being fuelled by population growth and rapid urbanisation. Agriculture holds great promise for broad-based economic growth and job creation.

Successful agricultural transformation means the existence of two simultaneous developments: [13]. Productivity (output per unit of input, variously defined) increases sustained over two to three decades at least; and Sustained income increases for the majority of farm/rural households.

On the other hand "successful rural transformation" means income increases of the majority of rural households, sustained over decades. The cumulative increases of broad-based on-farm productivity and off-farm rural income increases, fundamentally improve the lives and prospects of millions, (hence "transform"), of current and future generations of rural households.

In recent years, there has been a lot of optimism about Africa's economic growth prospects. There were noticeable positive achievements in Africa, such as increasing foreign investment, less conflict and more democracies than at any other time in the continent's history, the optimism is well-justified. However, we still face major challenges. Among these is the fact that agriculture remains an unattractive option for many of our young people in rural areas. It is worth noting that to absorb some of the 11 million young people entering the labour market every year in Africa, agriculture must become a growth sector, a source of prosperity and a global business. This is a paradigm shift needed in Africa's agriculture sector. As agriculture gets modernised, many new specialised jobs gets created, including jobs that are particularly well-suited to youth trained specially in those new fields. This takes a strategy and policy development at national level. This action must be accompanied by some sort of campaign to "transform the image of agriculture from a low-paying, awkward and tedious occupation to one that is profitable, modern and respectable" [14].

Africa must make it a priority to attract investment into agriculture. CAADP framework should be used by all African government to do this. Nonetheless a lot more need to be done to transform African agriculture to a more business like, profitable and sustainable pathway. Improved seeds and additional fertilizers are needed but induction of new technologies is necessary. Therefore greater investment in research and innovation is key to transformation so that more of Africa's agricultural growth comes from productivity increase rather than land expansion. Transformation will be considered on its way when small holders get integrated into the value chains, and access to finance, new markets, and training on how to handle their own expansion. This all will rely on an enabling environment and supportive institution for smallholder agriculture to grow.

\subsubsection{Challenges to Agricultural Transformation}

\section{1) Production and Productivity (under capitalization)}

Table 1 describes how far behind some Africa's staple crops yields are compared to 
other regions in the world. Agricultural transformation in Africa is faced with tremendous challenges. It will take strong and engaged political will to tackle some of those challenges to make way for a sustainable transformation, leading to a breakthrough in food security and wealth creation for the small scale farmers. The following are some of the challenges which need to be overcome: under-capitalization, inadequate funding for fundamental and applied research and technology, low utilization of yield enhancing inputs (mechanization, chemicals and irrigation), as well as poor extension services and access to credit, inferior output and low value added (low or minimal value addition), adverse Impact of climate change, poor market infrastructure and fragile agricultural/food markets, lack of awareness on the importance of investing in rural transformation, inefficient/lack of supporting institutions such as regulatory frameworks, social protection in general and insurance scheme in particular in addition to low human capacity, unsecured access to land, and sometimes, lack of political will. African agriculture needs its own green revolution. The one enriched by the lessons learnt from the Asia green revolution and that of elsewhere. This is definitely needed for the increased demand of food. African farmers intensively depend on rain-fed agriculture thus highly prone to climate change impacts. Steadily increasing demand for food, regionally as well as globally, aggravates the situation.

The situation is exasperated by the way Africa population is growing. This gives not much choice rather than developing an agricultural sector that can meet this ever growing demand for food products. By 2030, more than 600 million Africans will live in rural areas (World development report, 2008) [15]. The majority will rely on agriculture for their livelihoods. According to Ligon and Sadoulet (2007) [16], the poorest household gets, up to 4 times more benefits for a 1 percent GDP increase if this increase is based on agricultural rather non-agricultural growth. The challenge remains to boost agricultural productivity by increase inputs, environmental technology, incorporation of indigenous knowledge and local participation and ownership.

Table 2 refers to staple crops production in Africa compared to other regions of the world. Africa still lags behind in staple crop production compared to other regions of the world. For instance while Africa produced a total of 69.6 million tons of maize in 2012, North America produced 285.5 million tons and, Western Europe 240 millions and USA 274 million tons.

\section{2) Addressing the double disconnection of farmers}

Table 1. Yield per ha for some basic staple crops: Africa compared to the rest of the World (MT).

\begin{tabular}{cccccc}
\hline Mt/ha & Africa & Asia & Western Europe & Central America & Vietnam \\
\hline Maize & 2 & 5 & 9.4 & 2.9 & 4.2 \\
Rice (paddy) & 2.5 & 4.4 & 5.9 & 3.6 & 3.6 \\
Wheat & 2.4 & 3 & 7.4 & 5.6 & 5.6 \\
\hline
\end{tabular}

Source: FAOSTAT, 2012 data (Author's compilation). 
Table 2. Staple crops Production/Year 2012/FAOSTAT.

\begin{tabular}{|c|c|c|c|c|c|c|c|c|}
\hline (tons) & Mali & Zimbabwe & Africa & N. America & C. America & S. Asia & W. Europe & USA \\
\hline Maize & $1,713,729$ & $1,000,000$ & $69,636,488$ & $285,535,230$ & $25,920,416$ & $30,972,411$ & $23,998,071$ & $273,832,130$ \\
\hline Wheat & 40,069 & 42,000 & $24,710,632$ & $88,768,140$ & $3,283,287$ & $140,050,498$ & $67,644,205$ & $61,755,240$ \\
\hline
\end{tabular}

Source: FAOSTAT, 2012: Author's calculation.

Since its independence in the 1960's up to date, the most fundamental development challenge for Africa has been how to reach its own food security? Throughout the world, and particularly in South Asia and sub-Saharan Africa, many of the poorest people are farmers. Nearly 75 percent of those subsisting on $\$ 1$ a day live in rural areas, and it is estimated that the majority of the poor will remain rural until 2040 (Ravallion et al., 2007) [17]. At the same time, agriculture is a major source of income and employment in these regions: it accounts for about 34 percent of Gross Domestic Product (GDP) and 64 percent of the labor force in sub-Saharan. Africa. Poverty alleviation is therefore directly linked to agriculture. Whether in the form of new crops, improved seeds, improved breeds of animal, or changes in agricultural practices and crop choice, technology has the potential to sharply increase yields, reduce spoilage and risk, and improve the nutritional quality of food. Therefore transformation is imposing itself to Africa agriculture. The key lies in increasing the agricultural income of smallholder farmers and creating rural off-farm employment opportunities. Small holders find themselves in an awkward situation, being disconnected from the input market and at the same time disconnected to the product markets. They usually face the sellers market when buying inputs and also face the buyers' market when selling products. Therefore they are subject to the usual deterioration of the terms of trade. Smallholder farmers need to benefit from the greater value addition to their products so they can break away from absolute poverty. Hence the need for such a working paper to highlight the need for and challenges to agricultural transformation with a view of raising awareness on the importance of agricultural and rural transformation as an effective means to reduce poverty through food production, marketing and wealth creation. While the focus of this working paper is to promote regional value chains in agriculture for increased food, it reviews the problems beyond agricultural production and productivity, to issues and opportunities associated with markets, value addition, employment, income generation, regional integration, inter-sectoral linkages, and general welfare.

\section{Role of the Value Chain in Agricultural Sector}

Simply defined, a value chain of a particular agricultural commodity links the steps a product takes from the farmer to the consumer. It includes research and development, input suppliers, production, processing, marketing and finance. According to handbook by Kaplinsky and Morris (2000) [18] "a value chain describes the full range of activities required to bring a product or service through the different phases of produc- 
tion, including physical transformation, the input of various producer services, and response to consumer demand. As such, value chains include the vertically linked interdependent processes that generate value. In contrast, the term supply chain is used internationally to encompass every activity involved in producing and delivering a final product or service, from the supplier's supplier to the customer's customer."

The value chain graph (Figure 1) shows the interconnections among various stakeholders in the economy.

Despite numerous commitments to create integration zones, the continent continues to register the lowest percentage of trade within the region worldwide-a mere $12 \%$ cent of total exports take place within Africa, compared with 25\% in ASEAN and over $60 \%$ in the European Union. This is largely a result of a mix of trade policies that have been heavily focused on gaining access to developed economies and regional integration efforts that were not fully implemented. For Africa the potential gains from increased regional integration are particularly substantial: 54 economies of Africa-of which almost half register a population of less than 10 million and more than a third being landlocked-make the continent the most fragmented region in the world. In addition, more than a third of African economies are landlocked.

\section{Need for Regional Value Chain for Increased Income and Increase Food}

Developing regional value chains for strategic agricultural commodities, especially those identified by AU Food Security Summit in Abuja, is essential for African countries to

Example of Value Chain Model: Graph adapted by Nassirou Ba. from Kaplinsky \& Morris (2000)

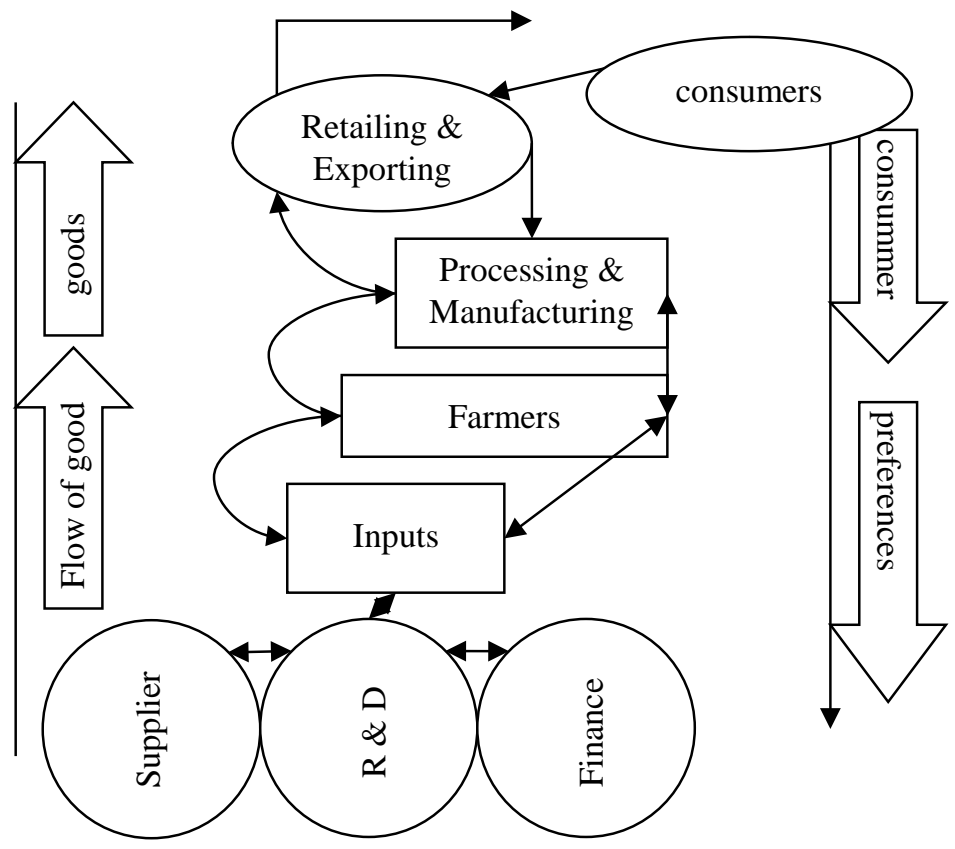

Figure 1. Value chain model. 
enhance their agricultural transformation and global competitiveness (AU, 2006) [19]. It is obvious that African countries will not make it to that global competitiveness if they were to operate on individual basis. Strategic partnerships are necessary to be formed among interested countries through regional value chains. This can also be used as a tool to support CAADP pillars, namely Pillar II and IV. Let's positively reiterate that the economic prospects of African countries are bright. Africa's population will reach 1.4 billion by 2020 , by which point, four out of every ten citizens $\left(4 / 10^{\text {th }}\right)$ will be residing in urban areas The increasing demand for processed agricultural products (Africa is importing $\$ 50$ billion of packaged food per year) will require the value chain impetus meaning adding value to farmers' outputs. New markets for value-added products will evolve, thus positioning value addition, triggering agribusiness and agroprocessing, coupled with induced services, as the cornerstone for food security and the path to unlocking prosperity in Africa, through creation of employment and new revenues. Unfortunately, Africa has carved itself presently to be a net importer of valueadded food (mostly packaged food); a vivid example of how the continent has failed to transform its "inherited natural wealth" into "created wealth". To alleviate this problem, African countries must promote agribusiness and agro-industries strategies that integrate rural infrastructure and support services for targeted commodity value chains based on specialisation and market demand. The way out for the agricultural sector is through value addition, wealth creation and retention into the system.

\subsection{Linking Small Holders to Inputs Market and Products Markets}

\section{Connection to the Inputs and Outputs Markets}

Why agriculture has remained in subsistence form in Africa? It is because the small holders has been overlooked and marginalized in the process of the value chains development. In order for the small holder to grow, he or she will need to understand what happen to the product when it leaves the farm gate and consequently need to operate in the chain and be part of the chain and also received benefits for its participation. Increase of productivity at farm level is expected to be achieved through additional use of fertilisers, use of improved seeds and appropriated and adapted more efficient agricultural practice an technologies. Therefore the smallholder needs to be connected to the input markets.

\section{1) Poor Diffusion of Technology}

The system of technology diffusion is sometime poor in Africa. Farmers who would benefit from technology adoption may be unable to access or pay for the technology due to inadequate system, missing supply chains or unaffordable high prices. Infrastructure, such as roads and irrigation, plays a key role in facilitating technology adoption, but putting those infrastructure investments in place is typically left to governments and foreign donors, because for private sector to undertake those investments, they need to be profitable up front, and usually they are not. Although the diffusion of technology is dependent to roads, irrigation system and sometime good transport system in the country, it is adamant to take care of those things first to expect on any suc- 
cess. Cross-countries evidence on the effect of infrastructure on agricultural productivity shows a positive relationship between productivity and the development of roads and irrigation. Improved transportation is also associated with diffusion of technology, better use of inputs and better prices for farmers.

\section{2) Poor Infrastructure and Weak Market Power}

It is frequent in Africa to see the market prices to be very far off from the farm-gate prices because of poor infrastructure. More often transport and storage cost drive a wedge between the prices that farmers receive for their output and the market price thus, lowering the profits associated with certain good agricultural practices and technology adoption. This is very often noticed in landlocked countries in particular where high transport cost is associated with the import and export of agricultural products. It is well documented in Africa that transportation can account for half of the cost of agricultural output marketing, a considerable fraction of the value of the product. The farmer is left with almost no profit from his products because input suppliers and output buyers face little competition, they impose their prices. In these cases, much of the profit from improved agricultural technologies may be captured by market factors other than the farmer. Therefore by raising the fixed cost of distribution, poor infrastructure, increase the market power of intermediaries (brokers) and thereof diminish that of the farmers. This is a discouraging effect that need to be brought up to policy makers attention so that the market is not monopolized by middlemen and thus creating the lack of confidence to the markets at the farmer's level.

\subsection{Inter Sectoral Linkage}

The concept of sectoral linkage has long been debated and used in theories of economic growth. It is a must that the primary, the secondary and the service sectors interact to push the agenda of growth. Most often depending on the way the sectors interact the $2^{\text {nd }}$ or the $3^{\text {rd }}$ sector takes over. The ideal is the primary sector feed the secondary sector and then the two get support from the service sector and they all grow. According to Hirschman's theory of unbalanced growth, "the technological relationship between different sectors is the prime mechanism of growth". According to him, each sector has linkages with the other sectors in an economy, in the sense that it either purchases inputs from them from the production of its output or provides them with its own output as input to the other sectors. Thus, "the expansion of any sector's output will, through technological inter-dependence, lead to the expansion of output of the other sectors" [20]. Agriculture being the primary sector in Africa, has always plays an important role in contributing to socio-economic development It is the primary source for employment, livelihood, and food security for the majority of rural people if not all. It is the engine which drives at first the rest of the economy and later on when industry and service sectors take off, its role diminishes. The success of this continuation depends largely on the direct impact it has on the national economy as well as how the agricultural sector stimulates the growth of other sectors in the economy. Consequently, understanding the role of agriculture and its linkages to the rest of the economy is impor- 
tant. The transformation of agriculture requires that industrialisation is involved and such activities like manufacturing, processing take place and in the course, the service sector kicks in. Africa needs to develop its manufacturing capacity to benefit for any productivity increase at the farm level. Without industrialisation (manufacturing), the expected agricultural transformation will not happen. Agriculture and industry are integral component of development process due to their mutual interdependence and symbiotic relationship, the contribution of agriculture to the economy in general and to industry in particular is well known in almost all the developing countries. The production linkages basically arise from the interdependence of the sectors for meeting the needs of their productive inputs, whereas the demand linkage arises from the interdependence of the sectors for meeting final consumption. Further, the linkages between the two sectors can also be categorized into two groups based on the direction of interdependence. One is the backward linkage, which identifies how a sector depends on others for their input supplies and the other is the forward linkage, which identifies how the sector distributes its outputs to the remaining economy. More importantly, these two linkages the potential capacity of each sector to stimulate other sectors and then reflect the role of this sector accordingly.

\subsection{Addressing the Fragmentation of African Food and Agricultural Economy}

\subsubsection{At National Level}

Agricultural markets in sub-Saharan Africa are fragmented for the people who need them most. The markets are not structured and sometime very far from the farm-gates. This sometimes create situation of post harvest losses especially for fresh products with short-life span without good storage conditioning. Transforming the sector means changing the usual way of business and, connecting the farm to markets, that will not only address the food security issues, the income issues, but also will unlock the subsequent trade and development potential more broadly. Market access can help drive sustainable productivity gains, improve livelihoods and reduce risks for smallholder communities; however, the process of building markets and making them more inclusive is not an easy endeavor. It will require public and private investment. This is necessary to contain the growing consumers demand, especially from urban area. Population in Africa is set to almost double to two billion by 2050, and current food production systems in Africa will only be able to meet $13 \%$ of the increased demand. At the same time, across Africa it is estimated that $80 \%$ of the population depends on agriculture for their livelihoods.

\subsubsection{At Regional Level}

At regional level, the same issues are valid. The African market remains highly fragmented; preventing enormous opportunities for cross-border trade from being exploited and in turn generating new jobs. Most countries in Africa have a population less than 15 millions people and, while in Europe and North America, countries are striving to get together in commercial union in order to form and access larger markets. The 
Regional Economic Commissions are struggling to form such regional markets but efforts are slow coming forth. Effective regional integration is more than simply removing tariffs; it is about addressing the barriers that undermine the daily operations of ordinary producers and traders of both goods and services. The incidence of barriers to regional trade fall most heavily, and disproportionately, on the poor traders, mostly African women traders who earn their living by trading goods across countries, and is preventing them from earning a simple living in activities where they have a comparative advantage, such as crafting, catering trading cereals and staple food in local markets and sometimes across the borders. Action is required at both the national and regional levels. Regional communities can provide the framework for reform but responsibility for implementation lies with each member country.

\section{Role of Agribusiness and Agro-Industries}

It is undisputable that the future of Africa agriculture lies in agribusiness development and strengthening of value chains. This needs to be looked at both national level and regional level. African governments, leaders and policy makers seem to all agree on this concept but when it comes to implementation there are still hurdles and slowness. The development of agribusiness and agro-industries and the food manufacturing in general will have multiplier effect and induced sectoral linkages, creating jobs, creating and increasing income and resulting in economic growth.

\subsection{State of Africa Agribusiness Landscape}

Figure 2 exhibits the level of interaction in the subsector from input production up to the final stage of consumption of the product.

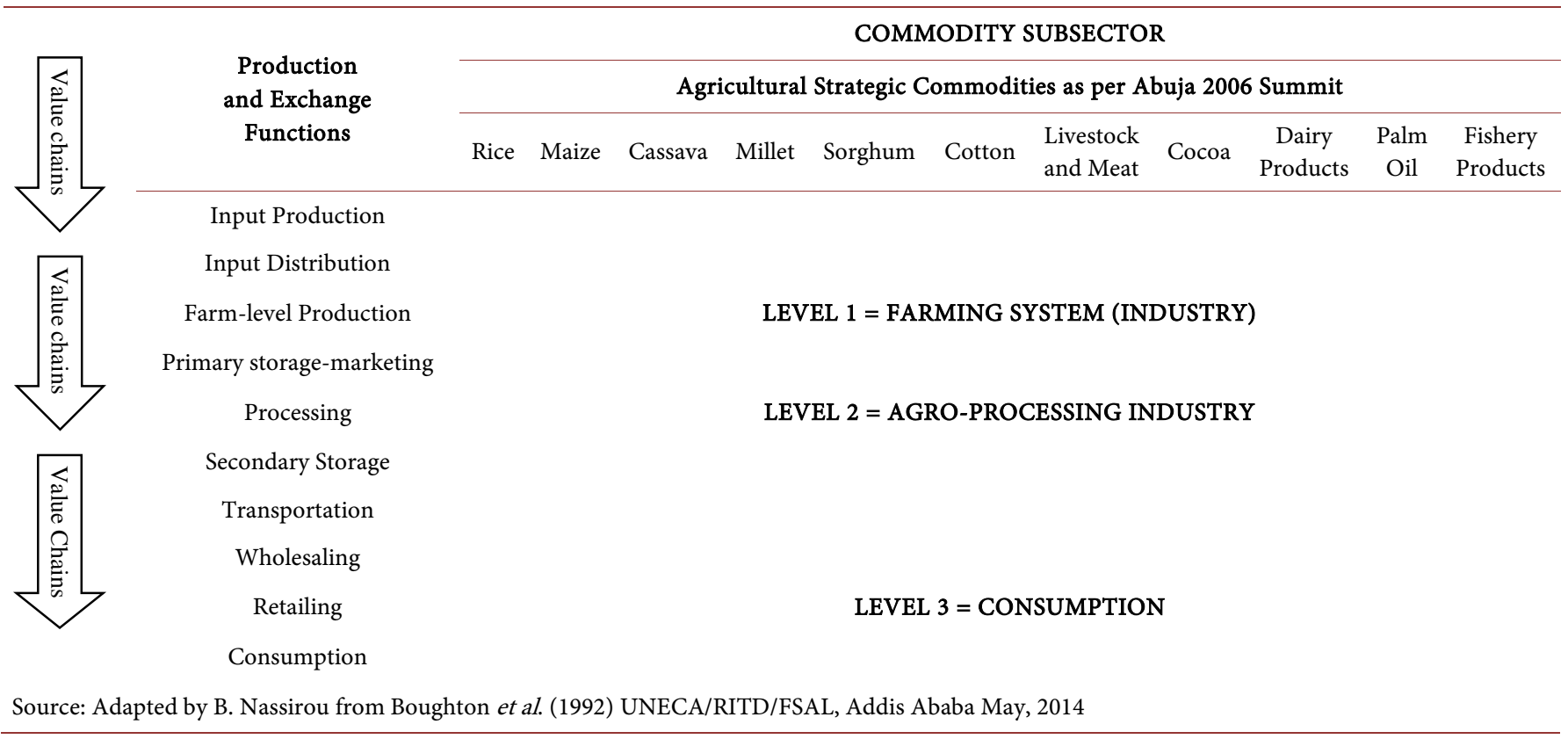

Figure 2. Strategic agricultural commodities sub sector. 
According to the International Standard Industrial Classification (ISIC), agribusiness and agro-industries consist of six sub-sectors, namely: food and beverages; tobacco products; paper and wood products; textiles, footwear and apparel; leather products, and rubber products. Agribusiness and Agro-industry, by definition, include all the post-harvest activities that are involved in the transformation, preservation and preparation of agricultural production for intermediary or final consumption, marketing, financing, up to the consumers and even sometimes beyond consumers up to decommissioning.

The various factors and conditions shaping agro-industries and agribusiness in Africa include geography, natural resources and factor endowments, climate, scope and coherence of policies, political environment, business environment, impacts and outcomes of industrialisation strategies and types of integration with regional and global markets and the resultant degree to which the development potential can be exploited (UNIDO, 2012) [21]. In recent years, African countries have demonstrated renewed commitment to industrialization as part of a broader agenda to diversify their economies, build resilience to shocks, develop productive capacity for high and sustained economic growth, create employment opportunities and substantially reduce poverty. Virtually all cases of high, rapid and sustained economic growth in modern economic development have been associated with industrialization, particularly growth in manufacturing production. The necessity for structural change in Africa also arises from the fact that Africa needs high and sustained economic growth in order to make significant progress in reducing poverty. According to UNCTAD data (August 2013) [22], the state of industrial and manufacturing development in Africa is weak and has not been improving with time. Manufacturing is known to be the engine to drive value addition and job creation and sustainable economic growth.

\subsubsection{Percentage Shares in Manufacturing}

For example, the share of African manufacturing in gross domestic product (GDP) rose from a low of 6.3 per cent in 1970 to a peak of 15.3 per cent in 1990, and thereafter fell to 12.8 per cent in 2000 and 10.5 per cent in 2008 . What is interesting to note is that the decline in the contribution of manufacturing to GDP since 1990 has been observed in all sub-regions of the continent. In Eastern Africa, the share of manufacturing in GDP fell from 13.4 per cent in 1990 to 9.7 per cent in 2008. In Western Africa it fell from 13.1 per cent to 5 per cent over the same period. Furthermore, in Southern Africa, it fell from 22.9 per cent to 18.2 per cent and in Northern Africa from 13.4 per cent to 10.7 per cent. Africa still accounts for a very low share of global manufacturing.

Table 3 shows how much need to be done in manufacturing in Africa, knowing that it is that sector which create job and where income through value addition.

\subsubsection{Percentage Shares in Manufacturing Value Added}

The share of the region in global manufacturing value added fell from 1.2 per cent in 2000 to 1.1 per cent in 2008. In developing Asia, it rose from 13 per cent to 25 per cent and in developing countries in Latin America it fell from 6 per cent to 5 per cent over 
the same period. There has also been no significant change in the region's share of global manufacturing exports in recent years, although Africa's share of global manufacturing exports rose slightly from 1 per cent in 2000 to 1.3 per cent in 2008. Africa policy makers have recognized the necessity to promote industrial and manufacturing development in order to address Africa's development challenges.

As shown in Table 4, Africa as a whole displays a 10\% MVA as a percentage of GDP. All the other selected countries here have not show much progress from 2005 to 2012. During the 7 years span of the data collected by UNIDO none of the selected countries here show tangible increase in the percentage of MVA in their GDP.

Table 3. Percentage in world manufacturing value added.

\begin{tabular}{cc}
\hline Regions & \% in World Manufacturing Value Added (2010) \\
\hline Industrialised Nations & 67.7 \\
North America & 22.4 \\
Europe & 24.7 \\
East Asia & 17.2 \\
Developing Nations & 32.3 \\
Latin America & 5.8 \\
Asia \& Pacific & 21.7 \\
Africa & 1.5 \\
\hline
\end{tabular}

Source: Author's computation from UNIDO STATISTICS (IndStatbrief, 2013).

Table 4. MVA as percentage of GDP.

\begin{tabular}{ccc}
\hline Countries & MVA as \% of GDP (constant 2005 price) \\
\cline { 2 - 3 } & Year 2005 & Year 2012 \\
Africa & 9.99 & 9.99 \\
Ethiopia & 4.25 & 4.23 \\
Kenya & 10.41 & 10.25 \\
Rwanda & 6.67 & 6.57 \\
Zambia & 10.26 & 10.17 \\
South Africa & 15.24 & 15.11 \\
Nigeria & 3.07 & 3.09 \\
Mali & 2.16 & 2.52 \\
Cote D'ivoire & 17.99 & 17.87 \\
Central. Afr. Republic & 5.38 & 5.40 \\
Algeria & 4.87 & 4.71 \\
Egypt & 15.96 & 16.38 \\
Madagascar & 13.39 & 13.33 \\
\hline
\end{tabular}

Source: Author's computation from UNIDO STATISTICS (IndStatbrief, 2013). 
As mentioned above Africa will not make it to a substantial industrialisation if there is no breakthrough in manufacturing.

\subsection{Africa Agribusiness and Agro-Industries Development Initiative: 3ADI}

\subsubsection{Background}

The Africa Union Commission and its New Partnership for Africa's Development (NEPAD) through the Comprehensive Africa Agriculture Development Program (CAADP), aware of the need to strengthen Africa's agribusiness and agro industry sectors to spur its transformation along the lines of development of competitive, sustainable and inclusive agro-industries and agribusinesses in Africa as a pathway to increase economic growth and food security in the continent, partnered with the African Development Bank (AfDB), the Food and Agriculture Organization of the United Nations (FAO), the International Fund for Agricultural Development (IFAD), the United Nations Economic Commission for Africa (UNECA) and the United Nations Industrial Development Organization (UNIDO), to launch the African Agribusiness and Agroindustries Development Initiative (3ADI) during the High-Level Conference on the Development of Agribusiness and Agro-Industries in Africa (HLCD-3A), which was hosted by the Government of the Federal Republic of Nigeria in Abuja, Nigeria, in March 2010. It is again this backdrop that after decades of neglect, that agriculture is again receiving attention from African governments.

\subsubsection{Why the 3ADI Initiative?}

Africa has witnessed improved growth in recent years-averaging 5.5 per cent per annum. Nevertheless, poverty remains a serious challenge. This growth has not been inclusive, hence not sufficient to propel broad-based development. For growth to be translated into sustained poverty reduction, employment creation, income generation and improvement of livelihoods, greater attention needs to be placed on the quality of growth, its sustainability and spread. Agribusiness and agro-industries development have an important role to play in this context. They take agriculture to another dimension which is required for its transformation. Agricultural transformation is the process by which individual farms shift from highly diversified, subsistence-oriented production towards more specialized production oriented towards the market or other systems of exchange (e.g., long-term contracts). The process involves a greater reliance on input and output delivery systems and increased integration of agriculture with other sectors of the domestic and international economies. Agricultural transformation is a necessary part of the broader process of economic transformation, in which an increasing proportion of economic output and employment are generated by sectors other than agriculture. According to ECA Issues paper on "economic transformation, January 2013", four essential and interrelated processes define transformation: (i) a declining share of agriculture in GDP and employment; (ii) a rural-to-urban migration underpinned by rural and urban development; (iii) the rise of a modern industrial and service economy; 
and (iv) a demographic transition from high rates of births and deaths (common in underdeveloped and rural areas) to low rates of births and deaths (associated with better health standards in developed and urban areas). It is in this vain that we single out the definition of "agribusiness" to be agriculture conducted on strictly commercial principles, and "agro-industry" to be the type of agriculture engaged in as a large-scale business operation embracing the production, processing, and distribution of agricultural products and the manufacture of farm machinery, equipment, and supplies. In this case it is understood as a component of the manufacturing sector where value is added to agricultural raw products.

\subsubsection{What Can Agribusiness and Agro Industry Sectors in the Process Detailed above?}

Today Africa's food system is characterized by the gap between supply and demand of agricultural products. The demand for food and agricultural products is changing in an unprecedented way. This is due to several factors including increase in per capita incomes, higher urbanization and the growing of middle class people who are target for ready-made/packaged food. These new demands need to be met and are triggering the need to focus and strengthen Africa nascent agribusiness and agro-industries sectors.

In fact, while the central role of agriculture in Africa's economic development has been widely accepted, policy makers and development planners increasingly are recognizing the need to focus more attention to agribusiness and agro-industries in their strategies to promote economic development of the continent. Many ministries of agriculture, for instance, openly acknowledge in their mission statements and strategic plans the key role of agricultural value chains, commercial farming and value addition in contributing to economic development. The specific roles can be detailed as follows.

\subsubsection{Developing up Stream Activities}

The availability and accessibility of agricultural inputs, are two great daunting challenges for African farmers. This sector is crucial for a market-oriented agricultural production. But let's bear in mind, that there is a general consensus that investments in agriculture should go beyond improvements in on-farm productivity to cover agribusiness and agro-industrial development, if agriculture should be the engine of economic growth. As highlighted in the ECA's Economic Report for Africa, 2009 [23] "agriculture has not been sufficiently linked to agribusiness and agro-industries in the continent. Consequently, innovative programmes for strengthening these linkages are needed such as regional value chains programmes focused on their forward and backward linkages". These investments in these sectors produce significant multiplier effects, generating demand for agricultural products and associated inputs and services, creating on- and off-farm employment, enhancing incomes and contributing to value addition and increased public sector revenues. Through the development of agro-industries and agribusiness, access to markets, finance and technical assistance can be facilitated for smallholder farmers, promoting their inclusion into more modern and efficient value chains. 


\subsubsection{Developing Downstream Activities}

Processing and packaging are downstream activities which have employment creation and income generation potential which are key to the transformation. The potential of agribusiness and agro-industries activities as growth engines is well known. The World Development Report 2008 called attention to the fact that the share of agribusiness and agro-industries in GDP tends to grow as countries move from lower to higher levels of income. Through their forward and backward linkages, investments in these sectors produce significant multiplier effects, generating demand for agricultural products, processed and packaged food and associated inputs and services, creating on- and offfarm employment, enhancing incomes and contributing to value addition and increased public and private sector revenues. Through the development of agro-industries and agribusiness activities, access to markets, finance and technical assistance can be facilitated for smallholder farmers, promoting their inclusion into more modern and efficient value chains. The agro-processing activities of food commodities strengthen the role of 3ADI and hence increase food security in four major ways:

- by reducing post-harvest losses which estimates could be as high as 30 percent in cereals, 50 percent in roots and tubers, and up to 70 percent in fruits and vegetables according to UNIDO (2011) [24].

- by extending the shelf-life of food, making it easier to reach urban areas where most of the population is concentrated;

- by adding value to commodities and therefore increasing incomes and creating employment along the food chain from production to consumption; and

- by improving the quality and safety of foods through establishing appropriate certification, traceability systems and harmonization of standards, thus increasing access to markets.

\subsubsection{Developing Commercial Agriculture}

A powerful driver of agricultural growth is the development of commercial agriculture. The aim is to produce for the markets, add value to goods for local market and export, and develop local production capacities. Overall, Africa lags behind, accounting for less than 3 per cent of global gross output, and less than 1 per cent of global manufacturing output. It is worth noting that the benefit of commercial agriculture is the fact that it is driven by the market demand. It produces what the markets demands. In sum, the combined effects of employment gains, income enhancement, inclusiveness and food security promoted through commercial agriculture and agribusiness and agro-industries development strategy can effectively contribute to reducing overall poverty in Africa. Small farmers are enthusiastic when they see increase in their revenues and when they see less risk and spoilage due to post harvest. With regard to trade, despite the growing demand for higher-value processed agro-industry products, Africa is yet to make significant progress locally toward adding value to her primary agricultural commodities and to achieve compliance with international standards. Indeed, African countries contribute less than 10 percent to global value addition. Africa's international trade is dominated by primary commodity exports, which represent almost 60 percent of total export 
value, with the remaining 40 percent being accounted for by fuels.

\subsection{Commodity Based Industrialisation}

According to ECA publications, ERA 2103 [25], "Massive industrialization based on commodities in Africa is imperative, possible, and beneficial. Resource-rich countries show that commodity-based industrialization is possible-despite criticism that it is a hard industrialization path. Massive resource-based industrialization through value addition and linkage development will yield employment, income, price, and non price benefits, as well as dynamic benefits of diversified technological capabilities and deeper industrial structure. Progress has been seen in forward and backward local linkages to the hard, energy, and soft commodity sectors in some of the African countries. Ethiopia, Nigeria, South Africa, and Egypt present good examples of making the most of hard (industrial) commodities".

Industrialisation has now become a key element African countries are striving to achieve. Its multiplier effects are undeniable for the inclusive growth sought by Africa. In recent years, African countries have demonstrated renewed commitment to industrialization as part of a broader agenda to diversify their economies, build resilience to shocks, develop productive capacity for high and sustained economic growth, create employment opportunities and substantially reduce poverty. Virtually all cases of high, rapid and sustained economic growth in modern economic development have been associated with industrialization, particularly growth in manufacturing production. The necessity for structural change in Africa also arises from the fact that Africa needs high and sustained economic growth in order to make significant progress in reducing poverty. According to UNCTAD (2013) [26], the state of industrial and manufacturing development in Africa is weak and has not been improving with time. Manufacturing is known to be the engine to drive value addition and job creation and sustainable economic growth. For instance, the share of African manufacturing in gross domestic product (GDP) rose from a low of 6.3 per cent in 1970 to a peak of 15.3 per cent in 1990, and thereafter fell to 12.8 per cent in 2000 and 10.5 per cent in 2008 . What is interesting to note is that the decline in the contribution of manufacturing to GDP since 1990 has been observed in all sub-regions of the continent. In Eastern Africa, the share of manufacturing in GDP fell from 13.4 per cent in 1990 to 9.7 per cent in 2008. In Western Africa it fell from 13.1 per cent to 5 per cent over the same period. Furthermore, in Southern Africa, it fell from 22.9 per cent to 18.2 per cent and in Northern Africa from 13.4 per cent to 10.7 per cent. Africa still accounts for a very low share of global manufacturing. The share of the region in global manufacturing value added fell from 1.2 per cent in 2000 to 1.1 per cent in 2008. In developing Asia, it rose from 13 per cent to 25 per cent and in developing countries in Latin America it fell from 6 per cent to 5 per cent over the same period. There has also been no significant change in the region's share of global manufacturing exports in recent years, although Africa's share of global manufacturing exports rose slightly from 1 per cent in 2000 to 1.3 per cent in 2008 . Africa policy makers have recognized the necessity to promote industrial and manufac- 
turing development in order to address Africa's development challenges.

\subsection{State of Africa Industrialisation: Through the Lenses of Production and Export}

Looking at Table 5, one can conclude that in 40 years' time span Africa has not grown in terms of industrialization. It is sad to observe that from 1970 to 2010 Africa's percentage share of the world output has taken a downturn in the 2000 going from $2.17 \%$ to $1.85 \%$ and has now come back to the 1970 level of $2.73 \%$. At the same time, we have seen East Asia going from $9.83 \%$ in the 1970 to more than double in 2000 at $21.53 \%$, although it went down a bit in 2010 to reach $20.69 \%$. In terms of share in export Africa is still struggling to reach back to the 1970's level of 4.99\%. In 2000 its share in world export was only $2.31 \%$ which was a bit improving to reach 3.33 in 2010. While West Asia has taken off from its 1970 'level from a mere $2.25 \%$ to more than a quintuple in 2000 at $12 \%$, and continuing to increase to reach $17.9 \%$ in 2010 . The above percentages speak for themselves about Africa state of industrialization and this needs to be addressed. Africa food security can come from the development of the agricultural commodities value chains which in turns depend heavily on the nascent industrialisation. There must be a paradigm shift in Africa agricultural sector development, a complete $U$ turn, shifting from subsistence agriculture to commercial agriculture, to a marketdriven production. Africa needs to create new business partnership with the developed nations by inviting them to implant the transformation factories, the manufacturing and the processing plant here in Africa, so to not only create value, but also retain it in the continent and therefore boost its economic growth to a level which can create inclusive growth. The African countries are growing but have not been able to fulfil their industrial potential. This is due to a number of internal, external and historical reasons but mainly because of failure of policies, often imposed on Africa. With so many continental initiatives now on board such as PIDA (Program for Infrastructure Development in Africa), APCI(African Productive Capacity Initiative), IDDA (Industrialisation Development Decade for Africa), combined with the national initiatives, there must be room for harmonization and quick start for Africa industrialisation. The recipe for success include the following: (i) upgrading or creating commodity processing, (ii) create conducive environment with regulatory policy frameworks, (iii) increase PPP which has a critical role in harmonizing national and regional. States can do this in junction with the RECs.

Table 5. Percentage share of world output and global export for Africa and E. Asia (State of Industrialization in Africa in numbers).

\begin{tabular}{ccccccc}
\hline \multirow{2}{*}{ Regions } & \multicolumn{3}{c}{ \%Share in World Output } & \multicolumn{3}{c}{ \%Share in Global Exports } \\
\cline { 2 - 7 } & 1970 & 2000 & 2010 & 1970 & 2000 & 2010 \\
\hline Africa & 2.75 & 1.85 & 2.73 & 4.99 & 2.31 & 3.33 \\
East Asia & 9.83 & 21.53 & 20.69 & 2.25 & 12.02 & 17.8 \\
\hline
\end{tabular}

Source: Author's adaptation from ECA, ERA, 2013. 
The sad reality as mentioned above is that without boosting its industrialisation capacity namely, agricultural processing and manufacturing, Africa will remain at the lower end of the value chain. For instance regarding coffee trade: "up to 90 per cent of Africa's total income from coffee, calculated as the average retail price of a pound of roasted and ground coffee, goes to consuming countries" This clearly underscores the benefit to be realized and enjoyed by African countries if they were to increase value addition.

According to ECA Executive Secretary, during his speech on Commodity based Industrialization for Africa, "Africa's economic future will be determined by how the continent will design and implement effective industrial policies needed to promote industrialization and economic transformation".

\section{Enhancing Regional Markets and Trade}

Africa's share of overall world trade is insignificant and continues to decline. According ARIA IV (ECA, 2012), Africa's exports account for only 1.6 percent of global trade despite Africa having 13 percent of the world population. In agriculture, the share of Africa in world exports has dropped steadily, from 8 percent in 1971-1980 to some 3.4 percent in 1991-2000. In 2012, in total merchandise, the share picked up to $9.1 \%$ in world export and in primary products up to $11.6 \%$ (source: WTO, 2012) [27]. Regional trade and Intra-African trade have enormous potential to create wealth, employment, catalyse investment, lift people from poverty and foster growth in Africa. Over the period from 2007 to 2011, the average share of intra-African exports in total merchandise exports in Africa was 11 per cent compared with 50 per cent in developing Asia, 21 per cent in Latin America and the Caribbean and 70 per cent in Europe. Since the establishments of economic communities, African Governments have made several efforts to exploit the potential of trade for development, the most recent being the renewed political commitment by African leaders at the African Union summit in January 2012 to Boosting Intra African Trade and to fast tracking the establishment of a CFTA. To address the challenges impeding the flow of goods and services within the continent, policy makers must employ strategies that would strengthen Africa's infrastructure development. It is no doubt that infrastructure (soft and hard) and industrialisation are the key for boosting regional trade. The soft infrastructures are the command of the regional trade and efforts must be made to make them favourable to that cause. International trade has increased exponentially in recent years. According to UNCTAD [28] and WTO estimates, world merchandise exports grew by $2.1 \%$ in 2013 (current prices). The strongest exports growth was observed in developing Eastern Asia (6.5\%). At the same time, exports contracted the most in Northern Africa (-10.6\%). Imports grew particularly in developing countries of Western Africa (8.6\%) and Eastern Asia (6.2\%), while they decreased the most in developed Oceania $(-5.8 \%)$, followed by developed Asia (-5.5\%). Though African countries benefited from this increase, their share in world trade has remained low; Africa's export trade amounts to only about 3 per cent of world exports (ECA, 2013) [25]. 
While this poor trade performance is partly caused by trade protectionist policies of the advanced economies against African products, there are also constraints that inhibit trade within the continent There are several reasons for the weak regional trade performance in Africa, one of which is that the approach to regional integration on the continent has so far focused more on the elimination of trade barriers and less on the development of the productive capacities necessary for trade. While the elimination of trade barriers is certainly a great step, it will not have the desired effect if it is not complemented with policy measures to boost supply capacities (economies of scale). The limited role of the private sector in regional integration initiatives and efforts has also contributed to the weak trade performance of the continent.

RECS have not been able to fully mobilize resources (human and capital) towards the key trade related policy. Countries tend to stay in the protectionists side of things. Indeed, among the different measures that several advanced countries adopted in 2009 to curb the effect of the financial crisis, trade protectionism has been on the rise. Protectionism increased despite repeated assurances in the context of the G20 meetings in London, as well as in the context of World Trade Organization (WTO) talks. Experts say rapid conclusion and resolution of the outstanding issues in the Economic Partnership Agreements (EPAs) negotiations are crucial to Africa's medium-term prospects in both regional and international trade.

\subsection{Linkages}

\subsubsection{Markets Linkages}

The issue of regional markets is an "intra-African trade" issue. Africa has been performing bellow any standard in that area. To date the intra African trade is only 11. According to UNCTAD report (2013) [22] "Over the period from 2007 to 2011, the average share of intra-African exports in total merchandise exports in Africa was 11 per cent compared with 50 per cent in developing Asia, 21 per cent in Latin America and the Caribbean and 70 per cent in Europe." The biggest challenge Africa has today in terms of market access for agricultural products, is "how to grant its own food and agricultural products access to its own vast regional markets which is viciously exploited by western and Asian products. This is a problem and needs to be fixed. There is much to gain in enhancing and promoting regional trade, linking national farmers to national markets and linking national products to regional markets. There is no doubt that developing smallholder agriculture through national value chains and regional value chains can be effective in increasing food security, reducing poverty and hunger in Africa. But it should be noted that this should be supported through sustainable access to markets which in turn allows small holders/poor farmers to increase their incomes and lift themselves and their families out of poverty. For Africa to reverse its weak and declining competitiveness in both regional and global markets, it is important that African countries collaborate in regional frameworks through RECs such as COMESA, ECOWAS, ECCAS and others to create and sustain a competitive edge in commodities trade and transformation. This means therefore that strategic commodities must be 
identified according to comparative and competitive advantage in production and agro-ecological zones while marketing of commodities must take into account entire commodity value chain from input acquisition, production, transformation, storage, marketing, up to end use.

\subsubsection{Infrastructure Linkages}

Many African countries experience heavy post harvest lost due to the difficulties linked to lack of adequate storage facilities and distribution channels to regional markets where the products are most needed. According to a study by African Development Bank entitled "Developing Africa's Infrastructure for Enhanced Competitiveness": "Inadequate infrastructure has raised the transaction costs of business in most African economies". According to the same study, "Inadequate infrastructure has been estimated to shave off at least 2 percent of Africa's annual growth. Africa is still struggling with poor infrastructure, cumbersome procedures and tariffs and an unpredictable power supply. Poor infrastructures make trade physically difficult. Infrastructure plays fundamental role in the promotion of value chains. Intra-African trade is weak because fundamental aspects of trade logistics such as transport, energy and ICT remain serious challenge. The infrastructure deficit as observed around Africa is not only physical such as roads, ports, rails but also institutional such the rules and procedures that comes with moving goods across the borders. Regional markets are crucial for Africa's economic integration. Functional regional markets are sign of functional trade and hence functional supporting soft and hard infrastructures. African economies can begin the process of deep integration if their infrastructure networks are designed in such a way as to link production centres and distribution hubs across the continent, and national and regional markets, as the networks of developed economies do. Such infrastructure networks will enable Africa to compete effectively, tap into regional markets potentials.

\subsection{Continental Free Trade Area: CFTA}

Africa's participation in global trade has been marginal. Furthermore it is generally acknowledged that intra-African trade is significantly weak compared to trade within other regions in the world. On average over the past decade, trade amongst African nations is estimated at about $10 \%-12 \%$ while trade among North American countries it is in the range of $40 \%$, and among western European countries the rate is $63 \%$.

Enhancing intra-African trade should provide many opportunities within the continent to promote specialization among African countries; develop regional value chains to enhance diversification and competitiveness; and consolidate and integrate production infrastructure and processes across borders to achieve economies of scale. African countries therefore need to aggressively pursue comprehensive regional trade policies as a collective development and transformation strategy. From a continental strategic standpoint, stronger and deeper regional integration in Africa will not only help to promote sustainable economic growth and development, it will also enhance Africa's effective participation in the global economy, and make it less vulnerable to external 
shocks. It would promote exports to regional markets, build experience to enter global markets and provide a framework for African countries to cooperate in developing common services for finance, transport and communications. It is within this context, that the creation of a Continental Free Trade Area (CFTA) which would provide the basis for establishing a continental Customs Union and eventually the setting up of the African Common Market would substantially expand intra-African trade by breaking down tariffs and non-tariff barriers, and enhancing mutually advantageous commercial relations through trade liberalization schemes. The grand African CFTA will unleash the entrepreneurial dynamism and spirit across a continent without trade barriers and will represent an excellent opportunity for accelerating the achievement of the continental vision of an African Economic Community. Cognizant of the immense benefits to be derived from a Continental Free Trade Area, it is acknowledged that with or without the CFTA, the implementation by African Member States of a variety of proactive, remedial measures to address the current challenges militating against the free flow of trade in Africa, would significantly enhance the level of intra African trade. These measures form the basis for the Action Plan on Boosting intra Africa Trade. Both the Action Plan and the CFTA agenda, are intended also to deal with other problems such as the overlapping memberships of RECs, varying commitment levels of Member States to the regional integration agenda, as well as limited financial and human resources. The considerations outlined above, provided the context and strategic framework for the deliberations to be undertaken during Africa Trade Forum II in 2012 held in Accra Ghana.

\subsection{BIAT: Boosting Intra Africa Trade}

Figure 3 shows that UMA is the least exporters to Africa and also the least importer from Africa. UMA export to EU and import from EU is the largest. The table shows that the average of intra-Africa import is only $7.6 \%$ while the average of intra Africa export was about $13.5 \%$ in 2012. This is not a very good record for intra Africa trade. Intra-Africa trade has consistently remained minimal compared with its intercontinental trade. The pattern of African exports continues to be heavily influenced by historical links with the rest of the world as more than 80 per cent of African countries' exports are still destined for markets outside the continent.

RECs have fostered trade development through programmes aimed at achieving a free-trade area, a customs union, and a common market. However, numerous initiatives and decades of experimentation with integration in Africa have not brought about any significant levels in intra-REC and intra-African trade. The production and export structures of most African economies are geared to primary commodities such as minerals, timber, coffee, cocoa, and other raw materials, for which demand is externally oriented. Most lack the industrial capacity for diversified manufactured goods to support trade within regional markets. Sub-Saharan African countries appear to have relatively few goods to trade with each other. Inadequate infrastructure remains one of the chief obstacles to intra-African trade, investment, and private-sector development. 
Programmes to cultivate transport and communications networks, energy resources, and information technology would accelerate trade progress and transform Africa into a haven for investment. The implications of low intra-African trade are many and far reaching. Many opportunities are lost for using trade within the continent to enhance the prospects for specialization between African countries and accelerated development and integration. Intra-African trade can generate development and dynamic integration among African sub-regions and is a powerful driver of African growth and economic maturity. The main question, therefore, is how to reverse the situation so that African countries can benefit from improved intraregional trade.

\section{Value Chain Financing}

Figure 4 exhibits the inter linkage and financial information flow among stages of the value chains.

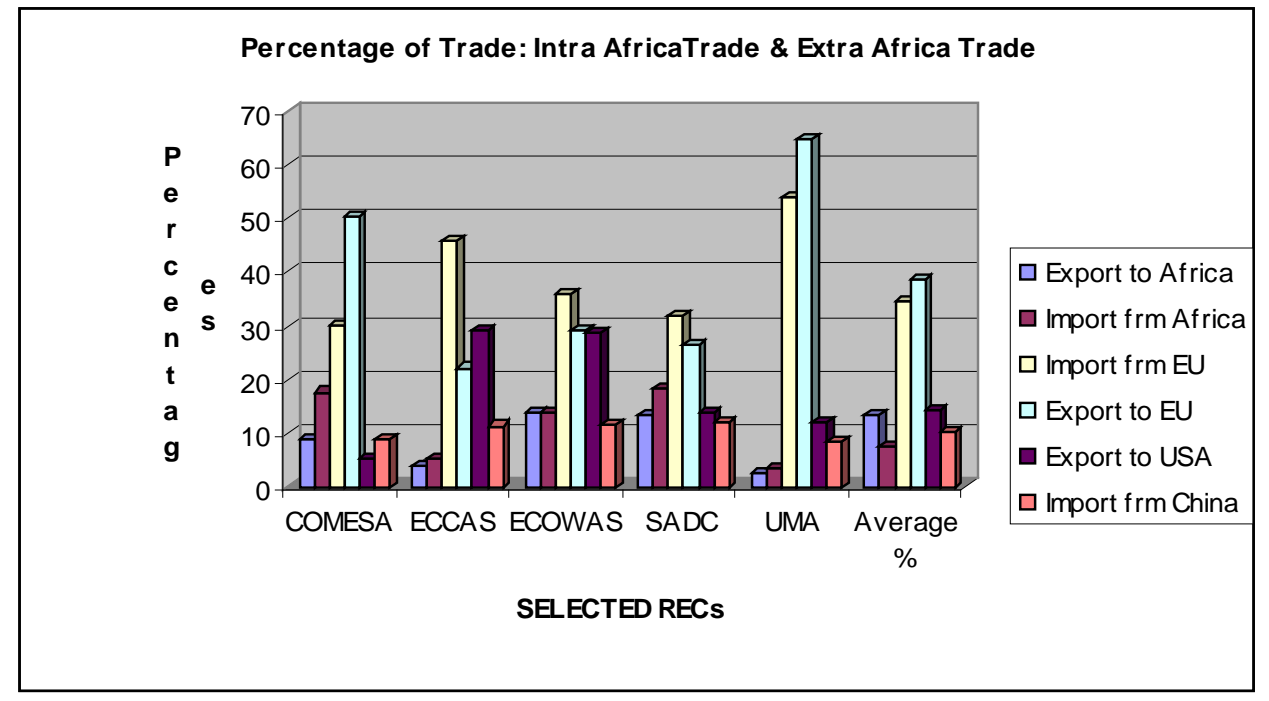

Figure 3. Trade Statistics among Africa's RECS and the World partners. Source: Compiled by the author from IMF data, Direction of Trade, April 2011 (ECA, ARIA V).

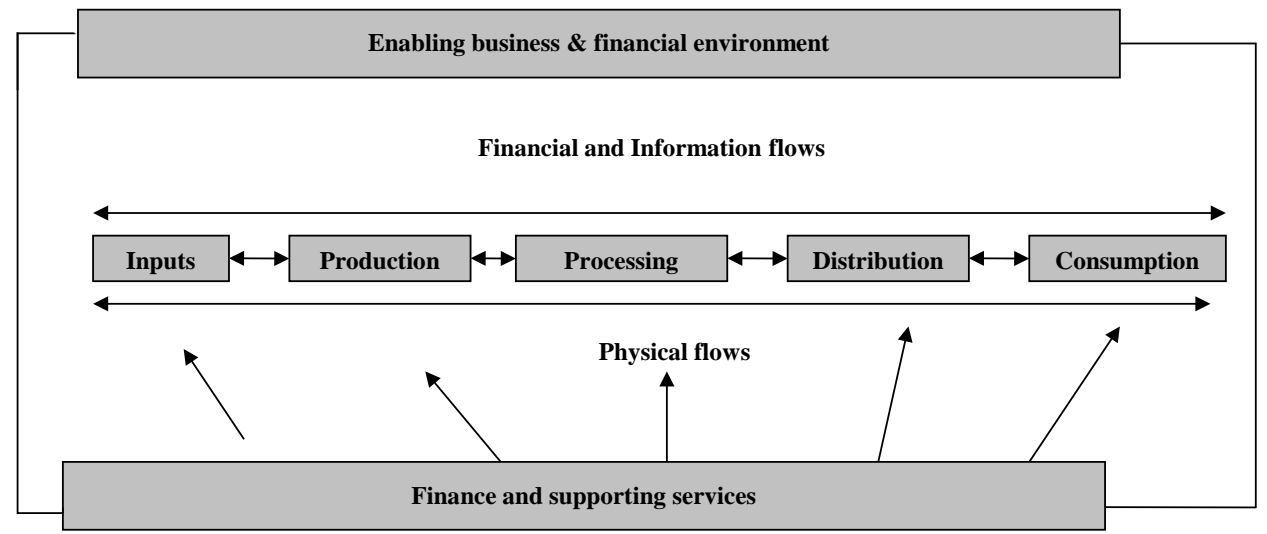

Figure 4. Value chain financing. Adapted by M. Nassirou Ba from G. Gereffi and Fernandez Stark, 2011, Global Value Chains Analysis. 


\subsection{Definitions}

As defined earlier in this document "value chain consists of a trail of activities and from one activity to another, value is added to the product up to its final form. It begins with the production, continuing with the processing, storage or elaborating of the final product, and ending with the marketing and sale to the consumer or end user". The value chain is a machine at work, an inter-dependent linkage of the chain involving suppliers, producers, processors, transporters, brokers and marketing companies operating from the perceived security of a market- driven demand for the final product. The way the chain is organized can reduce costs and risks of doing business and improve access to finance as well as other services needed by those within the value chain (vertical and horizontal chain). According to an FAO publication on value chains financing [29] "Value chain finance is defined as the flows of funds to and among the various links within a value chain-it is any or all of the financial services, products and support services flowing to and/or through a value chain to address the needs and constraints of those involved in that chain, be it a need for finance, a need to secure sales, procure products, reduce risk and/or improve efficiency within the chain". Value chain finance is a comprehensive approach which looks not only at the direct borrower but rather analyzes the value chain itself and how it works in order to best structure financing according to those needs. The linkages also allow financing to flow up and down the chain. For example, inputs can be provided to farmers and repaid directly from the sale of the product without having to go through a traditional loans process.

\subsection{Small Holders' Hold-Up}

It is not a secret that small holders have been marginalized and sometimes even discounted when it comes to "value chain finance". This is compounded from the fact that agriculture itself is generally considered a non profitable and risky sector at the small holder level and when it is modernized it over passes the level of the small holder and goes to the big entrepreneurs who deal with the financial institutions. How then can the small holder access financing? Most rural areas where smallholder farmers are located have none or limited financial institutions' networks. Even where they exist, smallholder farmers with poor credit rating, and sometimes with no collateral, will have no access to them, especially for medium-long term loans. It is been a practice all over Africa to see commercial banks avoiding to lend to agriculture in general because agriculture is generally assessed to be a risky sector. In addition, most commercial banks are normally located in the urban areas making them not readily accessible to the farmers. When they are in rural areas it is to collect cash deposits and savings from farmers with little assistance back to them. Many African countries are now establishing "Agricultural Development Banks" and putting out policies and strategies reinforced by agricultural finance products to assist small holder's farmers, especially women farmers to facilitate their access to credit and finance for their activities and to include them in the value chains. Financial services to smallholder farmers play a strong and pervasive role that affects not just the farmers, but the entire economy and society in general. 
In Africa most of the small holders are women and they are often bared from usual credit channels. They are left with small credit institutions or NGOs' level small credit schemes which barely can lift them from poverty. In a direct sense, credit makes smallholder farmers more productive and efficient. Access to readily affordable finance is one of the key factors that contribute to the development of agriculture. This has been the case in other regions of the world. While a lot of progress has been made in easing access, smallholder farmers have still very limited access to appropriate financing. For the agenda of strengthening value chains for increased food, it is a must to consider women farmers in the picture. The key reasons for their limited access to credit revolve around the high risk rating of the smallholder's farming as an agricultural sector, plus the diseconomies and related low profitability of lending to this market segment, need to be addressed. Many instruments have been designed and customized to address this issue. In terms of products, both the group and the individual loans have both been successfully used-with group loans reporting better loan portfolio quality than individual lending approaches in a number of countries in Africa. To achieve inclusive agriculture value chain financing there is a need to map successful small holders financing schemes in the continent and take stock of experience sharing. The following paragraphs (10.3) and (10.4) are examples of successful value chain financing.

\subsection{Rwanda Coffee Global Value Chain: Starbucks}

The example chosen here is from Spore Magazine. It concerns the Global value Chain of Starbucks with Rwanda Coffee growers. For the past 7 to 8 years with the help of Starbucks, the coffee growers of Rwanda have managed to expand and improve the maintenance of their plantations. Since 2004 Starbucks cut an agreement with the Government of Rwanda and the coffee growers of Dukunde Kawa cooperative to buy high quality coffee at a "fair trade price" and also helps the farmers to improve and increase their outputs. Starbucks offers loans to the cooperative, which supplies fertilizers and pesticides to the coffee farmers, which they repay when they sell their commodity. Using the proceeds of a collection among company staff, producers have even expanded their farm business by buying cows to use their manure in their farms. The farmers have also be learning techniques for hand-picking at the right ripping age. The Government of Rwanda has stepped in with contribution of Private sector and helped the coffee value chain sector by building coffee washing station equipped with pulping, sorting, fermentation, drying, and packaging machines. This public-private-partnership initiative has helped the quality of Rwandan coffee and subsequently increased it market selling price. The Rwanda coffee Global value Chain has created at least 5,000 jobs and continues to expand. Each year national and international coffee tasters come to test the coffee and give awards to the best coffee growers. The awards are sometime given in kind i.e. farm equipment, inputs, etc. It can be observed that in Africa agriculture value chain, the bulk part of the profit is concentrated in the hands of foreign partners. Wealth is created by the local value chain but it is not retained locally. This is obviously at the expense of national producers and national transformers. In the case of 
Rwanda coffee much hope is there for the price to continue to increase with the quality of the coffee and for the local farmers to increase their income on the path of poverty reduction.

\subsection{Small Enterprise in Milk Production in Kenya}

Mary Njeri Kamande is one Kenyan dairy farmer women whose story is referred to as a successful SME by the "Guardian". That small business moved from 1 cow milking business to 15 cows in a few years time and extended a small livestock range for pigs. She transformed herself to a creative entrepreneur and joined a cooperative (KMT) which offers a fixed demand and supply model with a set price. KMT was an entry-point for her, a break trough to the market. KMT assures high quality milk through testing upon purchase and in addition, industrially processes the milk before being resold. As such it also provides link to financial institutions and prepare its members to be financial credible (with business plans, cost/benefits analysis etc), soft assistance in the form of innovative market solutions, business strategy advice, and new business partners and technical assistance in business skills. It is only with these "soft" acquired skills, small cooperatives can compete against large companies given their access to better strategy advisors, closer political links and greater influence over market pricing. The income stability ensured justifies the proliferation of cooperatives over the last 50 years and so in Kenya. The country has close to 13,000 established units today facilitating market access for more than 1.5 million dairy farmers. It is no doubt that these cooperatives have played a magnificent role in the development and flourishing of the dairy industry in Kenya. The dairy industry contributes at the moment around 14\% of agricultural GDP and currently grows at $5 \%$ per year. In addition to providing market access, that would not be possible otherwise, dairy cooperatives provide assistance to farmers in issues crucial for profitable milk production, such as loans, artificial insemination and livestock rationing. A well fed cow can produce as much as 40 litres of milk a day or about four times that of a cow without appropriate dry food. For the local small-scale farmer, joining this competitive cooperative made her a successful entrepreneur, with a guaranteed monthly income and a production which is set to increase. This also provided opportunity to the employee of the SME to be trained in different aspects of milk production. In a nutshell, success in agribusiness in Africa calls for three essential factors, entrepreneurship, collective action, ideally in the form of cooperatives, and strategic partnership (story from the Guardian, May 2014).

\section{Conclusion}

Can value chains of agricultural commodities be taken as a means to increase food production in Africa? The short answer is "yes". This will necessitate an inclusive strategy of strengthening the capacity of actors along the chains (producers, processors, manufacturers), as well as enablers such as public and private institutions, service providers, policy and regulatory environment, etc. It all boils down to "policy environment". The development pattern recommended in this paper for agricultural com- 
modities value chain is "an integrated regionally coordinated value chain" which requires a regulatory policy framework and a strong political will from member states for implementation. The strategy needs to be anchored in a long term vision of value chain development for poverty reduction and accelerated economic growth. The gradual transformation expected from the agricultural sector will contribute to achieving food security, increased production and productivity, as well as expansion of income-generating activities and job creation. Africa through RECs should move the market integration beyond national borders to encompass regional and subregional markets: "Africa Common Market". One of the problems in Africa in general is the market fragmentation. This is so because there are asymmetries in perceptions of market and investment, there should be "one voice and one way". African needs to embrace a regional approach to its development to benefit from economies of scale and economies of complementarity of its different agro ecological zones. The businesses do not need to operate only in national and sub regional boundaries; they ought to project the big picture. In terms of trade such asymmetries translate to import from non-African sources. This causes trouble and setbacks to our economies. For example, today Africa's import bill is beyond $\$ 50$ billion dollars per annum for manufactured food. This $\$ 50$ billion could be reallocated among African businesses if borders and tariffs and non-tariffs fall down. The challenge remains in the area intra-African agricultural market access. Africa needs to grant access for its own (domestic) food to its own market. The level of African intra-trade in agriculture and food products is low in comparison with its total trade volume. According to FAO (2010) [30], only one-fifth of African food exports stayed in Africa, whereas 88 percent of Africa's total agricultural imports originated from outside the continent. However, the share of intra-trade of food over the total food trade varied greatly among commodities and was high in some cases. Cereals, live animals, meat, and dairy products were the most intra exported food products, representing 67, 61, 58 and 55 percent respectively out of Africa's total export of these products.

\section{Policy Recommendations}

- Appropriate policy enabling environment is needed in the continent: To meet the food demands of Africa's growing population and its changing diet. African countries must harness innovation and technologies (bio-food) to create sustainable food systems.

- A strong enabling environment with transparent and regulations, laws and trade policies is essential to value chain development and consequently to regional value chain development.

- Addressing the double disconnection of small holder farmers from inputs markets and product markets is a must. Inputs need to be available, affordable and accessible and increased food production need to be market driven.

- Market integration needs to move beyond national and subregional levels to reach regional levels (That is the vision of the "Africa Common Market").

- Regional production and processing belts need to be put in place based on compar- 
ative and competitive agro-ecological approach. The mapping of the potential of regional production and processing is necessary in order to optimally use scarce resources to built necessary infrastructure for such initiative: roads, factories, processing plants, communication technologies, energy, water schemes, technology research, etc. This is aimed at having commodity belts across RECS and other regional processing and manufacturing units with the view of galvanizing the regional markets, and take advantage of economies of scale, economies of vertical integration, and economies of complementarity.

- Unlocking the power of trade by using it as a tool for market development and productivity and income booster. Trade is an integral aspect of increased productivity and food security. Lowering tariff and non tariff barriers will continue to be a priority.

- African countries being characterised by fragmented markets where so many countries are also landlocked, regional integration and harmonization of laws and regulations will be critical to agricultural growth, and particular focus should be placed on how laws and regulations are being implemented in practice.

\section{Acknowledgements}

The author acknowledges the useful comments and edits suggestions from experts at the Climate Change and Development in Africa (CCDA V) Conference in Marrakech, Morocco in October 2014 organised by ECA/ACPC (Africa Climate Policy Centre). The CCDA is an annual forum designed to bolster linkages between climate science and development policy by promoting transparent discussions between key stakeholders in the climate and development community. He also acknowledges comments and edits received when he presented this paper at" Developmental States Conference "held in Pretoria, South Africa in July 2015, organized by UNECA/SRO-SA, OSISA (Open Society Initiative for South Africa), Southern Africa Trust and UNDP South Africa. The author is grateful to his Director, Dr. Stephen Karingi for his support in writing this paper. The author dedicates this paper to his uncle Ambassador Maki Koureyssi Aguibou Tall who was instrumental for his first scholarship for his Graduate Studies at University of California, Davis (UC Davis). He also acknowledges the support provided by two other uncles, namely Uncle Isma N'Diaye and Uncle Aguibou Dahirou Tall who guided him through his adulthood.

The author stresses that views expressed in this paper are those of the author and should not be attributed to the United Nations or the United Nations Economic Commission for Africa.

\section{References}

[1] FAO (1996) Food Security Summit. Rome. www.fao.org/forestry/13128-0e6f36f27e0091055bec28ebe830f46b3.pdf

[2] Human Development Report (2006) Beyond Scarcity: Power, Poverty and Global Water Crisis. UNDP. 
[3] (2013) World Population Data Sheet. Population Reference Bureau.

[4] FAO (2012) Why Africa Has Become a Food Importer.

[5] Imai, K.S., Gaiha, R. and Thapa, G. (2011) Role of Agriculture in Achieving MDG1 in Asia and Pacific Region. IFAD.

https://www.ifad.org/documents/10180/b08de076-0588-4851-9d14-3107dc342741

[6] World Bank (2013) Africa's Pulse: An Analysis of Issues Shaping Africa's Economic Future. http://www.worldbank.org/content/dam/Worldbank/document/Africa/Report/Africas-Puls e-brochure_Vol7.pdf

[7] Gallup, J., Radelet, S. and Warner, A. (1977) Economic Growth and the Income of the Poor. CAER Discussion Paper No. 36, Howard Institute for International Development, Cambridge.

[8] Thirtle, C., Irz, X., Wiggins, S., Lin, L. and McKenzie-Hill, V. (2001) Relationship between Changes in Agricultural Productivity and the Incidence of Poverty in Developing Countries. DFID, Imperial College, London.

http://eprints.ibu.edu.ba/2400/1/8.\%20Abdelhafidh\%20Dhrifi.pdf

[9] GRAIN (2007) A New Green Revolution for Africa. https://www.grain.org/article/entries/74-a-new-green-revolution-for-africa

[10] UNECA. Food Security and Human Development in Africa: Strategic Considerations and Direction for Further Research.

http://www.uneca.org/sites/default/files/uploaded-documents/AEC/2010/Papers/session_iii .1.3_2_food_security_and_human_development.pdf

[11] Staatz, J. (1998) What Is Agricultural Transformation? Michigan State University, East Lansing. http://fsg.afre.msu.edu/ag_transformation/Def_Trans.htm

[12] UNECA and ERA (2005) Theme: Meeting the Challenges of Unemployment and Poverty in Africa. http://www1.uneca.org/era/era2005.aspx

[13] Tsakok, I. (2011) Success in Agricultural Transformation: What It Means and What Makes It Happen. Cambridge University Press, Cambridge. http://dx.doi.org/10.1017/CBO9781139003759

[14] CTA (2014) Report on Transforming Agriculture, Critical to Future Growth in Africa.

[15] World Development Report (2008) Agriculture for Development. https://openknowledge.worldbank.org/handle/10986/5990

[16] Ligon, E. and Sadoulet, E. (2007) Estimating the Effects of Aggregate Agricultural Growth on the Distribution of Expenditures. Background Note for the World Development Report 2008, the World Bank, Washington DC.

[17] Martin, R., Chen, S. and Sangraula, P. (2007) New Evidence on the Urbanization of Global Poverty. Population and Development Review, 33, 667-701. http://dx.doi.org/10.1111/j.1728-4457.2007.00193.x

[18] Raphael, K. and Morris, M. (2000) A Handbook for Value Chain Research.

[19] Africa Union (2006) Summit on Food Security in Africa. Abuja. http://www.fanrpan.org/documents/d00188/AU_Abuja_declaration_Dec2006.pdf

[20] Hirschman, A.O. (1958) A Strategy for Economic Development. Yale University, Yale.

[21] UNIDO. Agribusiness for Africa Prosperity https://www.unido.org/fileadmin/.../Agro-Industries/Agribusiness/AAP_CCS_v4.pdf

[22] UNCTAD (2013) Global Commodities Forum: Recommitting to Commodity Sector for as an Engine of Eco Growth and Poverty Reduction. 
http://unctad.org/en/pages/meetings/GCF 2013.aspx

[23] United Nations Economic Commission for Africa (2009) Developing Africa Agriculture through Value Chains. Econo- mic Report for Africa.

http://www.uneca.org/publications/economic-report-africa-2009

[24] UNIDO (2011) Agribusiness for Africa Prosperity. https://www.unido.org/.../Agribusiness_for_Africas_Prosperity_e-book_NEW.pdf

[25] ECA (2013) Making the Most of Africa's Commodities: Industrializing for Growth, Jobs and Economic Transformation. Economic Report for Africa.

www.uneca.org/publications/economic-report-africa-2013

[26] UNCTAD (2013) Intra African Trade: Unlocking Private Sector Dynamism. Economic Development in Africa Report.

www.unctad.org/en/PublicationsLibrary/aldcafrica2013_en.pdf

[27] WTO (2012) Factors Shaping the Future of World Trade. www.wto.org/english/res_e/booksp_e/world_trade_report13_e.pdf

[28] UNCTAD (2013) Development and Globalization: Facts and Figures.

[29] Miller, C. and Jones, L. (2010) Agricultural Value Chain Finance: Tools and Lessons. FAO Publication.

http://www.fao.org/docrep/017/i0846e/i0846e.pdf www.fao.org/docrep/017/i0846e/i0846e http://dx.doi.org/10.3362/9781780440514

[30] FAO (2010) Why Africa Has Become a Net Food Importer. http://www.fao.org/docrep/015/i2497e/i2497e00.pdf

Submit or recommend next manuscript to SCIRP and we will provide best service for you:

Accepting pre-submission inquiries through Email, Facebook, LinkedIn, Twitter, etc. A wide selection of journals (inclusive of 9 subjects, more than 200 journals)

Providing 24-hour high-quality service

User-friendly online submission system

Fair and swift peer-review system

Efficient typesetting and proofreading procedure

Display of the result of downloads and visits, as well as the number of cited articles Maximum dissemination of your research work

Submit your manuscript at: http://papersubmission.scirp.org/ 